\title{
PATH LEARNING ALGORITHM FOR FULLY INDIGENOUS MULTIMEDIA AND GUIDE ROBOT
}

\author{
Rajesh Singh ${ }^{1}$, Anita ${ }^{2}$, Jatin Khilrani ${ }^{3}$, Ambuj Sah' ${ }^{4}$, Manish Parmar ${ }^{5}$, Shiv Kumar ${ }^{6}$ \\ 1,2,6 Lovely Professional University, Jalandhar, India \\ ${ }^{3}$ American Megatrends India Pvt. Ltd \\ ${ }^{4}$ DIT University \\ ${ }^{5}$ Nanhi Pari Seemant Engineering Institute, India \\ E-mail: srajssssece@gmail.com, eranita5@gmail.com
}

\begin{abstract}
A fully indigenous guide and multimedia robot, is designed to welcome guests and visitors and guide them for campus-tour with appropriate multimedia information. Path leaning algorithm is developed for the robot to make it follow a defined route in the University campus. It can interact with visitors and play multimedia on screen. ZIGBEE nodes are placed at few predefined locations and when robot reaches in its range, it starts playing the information regarding that location. To reach the predefined location robot uses obstacle avoidance using bubble rebound algorithm. It also uses training data set I for the calculation of distance and time with respect to routeand training data set II to get the heading in degree from magnetic compass as machine learning. A robotic Arm is connected to welcome guest by positioning 'NAMASKAR'. Obstacle avoiding algorithm is applied to avoid collision in the way. Design of robot and verification of results has been performed and result shows no error in the path learning. Paper covers the complete technical specifications and steps to design the robot.
\end{abstract}

Keywords: Path Learning, Multimedia, Robot, Obstacle Avoidance.

\section{Introduction}

Pai, Neng-Sheng, et al. (2014) discussed the development of an omni directional robot with RFID and speech recognition. Speaker is used for speech database with Viterbi algorithm [1]. Bennewitz, Maren, et al. (2005) proposed an approach to demonstrate the motion pattern to improve the navigation of the robot. Laser range finder with expectation maximization algorithm is used for data recording [2]. Rodriguez-Losada, Diego, et al. (2008) discussed a platform for navigation algorithm. A platform for sharing the advances and get the funding is also proposed and results were analyzed [3]. Thrun, Sebastian, et al. (2000) described the deployment of tour guide robot 'Minerva' in a Smithsonian museum. The robot interacted with thousands of the people. The robot moves in the museum at a speed of $163 \mathrm{~cm} / \mathrm{sec}$ [4]. López, Joaquin et al (2011) discussed the software complexities to design a robot. The programming tool RoboGraph is used for robot development. Signal Interpreted Petri Net editor is used for describing the task. The proposed system is used in many applications as guide robot (GuideBot) [5]. Wang, Meng etal (2005) proposed an interactive control for robot teleoperation using joystick. Each joystick performs defined task with events. The algorithm was tested on real robot through internet control [6]. Sulaiman,
Hamzah Asyrani, et al. (2013) developed a tour guide with PIC16F877A. The robot was controlled with GUI for navigation. The robot was capable of shape recognition and path planning which makes it suitable for various applications [7]. Javier Rainer, J., et al. (2011) proposed an autonomous presentation generator. It is designed with the help of the fuzzy system with genetic algorithm for the rules evolution [8].Chen, Zhichao et al. (2009) presented path learning concept for the robot based on vision approach. The coordinates are found with concept of funnel lane. The proposed algorithm is qualitative and don't need map [9]. Hua, Bin, et al. (2017) proposed a wheelchair robot for indoor navigation. The navigation of robot is done with the help of neural network and error is analyzed [10]. Ssin, Seungyoub, et al. (2014) introduced a method to direct the robot with image data. To perform the task images using TCP/IP protocol are taken from 2D camera [11]. Surmann, Hartmut (2003) presented an autonomous system for 3D indoor environments. It is divided in three modules to perform different tasks. The proposed system founds to be fast and reliable foe 3D digitization [12]. Biswas, Joydeep et al. (2010) discussed the autonomous navigation of the robot using WiFi sensory data. to update the location localization algorithm is used [13]. BoninFont, Francisco et al. (2008) discussed the vision based navigation for the robot. Map based and 
mapless approaches are used for navigation of land, underwater and aerial vehicles [14]. Liu, Hui, et al. (2007) attempted to identify techniques for indoor navigations and solutions. The properties for location are evaluated and this evaluation data is applied on existing systems for performance analysis [15]. Chen, Haoyao, et al. (2010) proposed a simultaneous localization and mapping technique for multirobot and its global localization. The algorithm is applied on group of robots for experimental purpose [16]. Choi, Byoung-Suk, et al. (2011) discussed a robot localization techniques using RFID.

The localization of system is done with the help of ultrasonic sensor. The estimation of position is with the combination of two algorithms GE and LEC and it is tested through experiments [17]. Nguyen, Viet, et al. (2007) proposed a 2D laser scan based indoor navigation. To evaluate the algorithm two office environments are considered. The experiment is tested for six different algorithms for results evaluation in SLAM application [18]. Ranganathan, Parthasarathy, et al. (2002) described execution of robot in buildings. This is achieved with the help of ultrasonic belt and camera. Free space to navigate robot is done through topological graphs [19]. Lee, Dongheui, et al. (2006) proposed a strategy for indoor localization. To resolve the problem of localization for dynamic changes an integrated algorithm is proposed including robot behavior and computational schemes [20].Feng et. al. discussed the reactive navigation in complex environment. It also uses value iteration algorithm for real time path planning.[22] Jiang et. al. [2015] discussed the segmentation select training data using neural network, for learning [23]

\section{Some robots available with previous art:}

1) Urbano (Fig. 1) is specially designed for tour guide in exhibition the main target areas for urbano are indoor environments, populated environments and low structured environments [3].

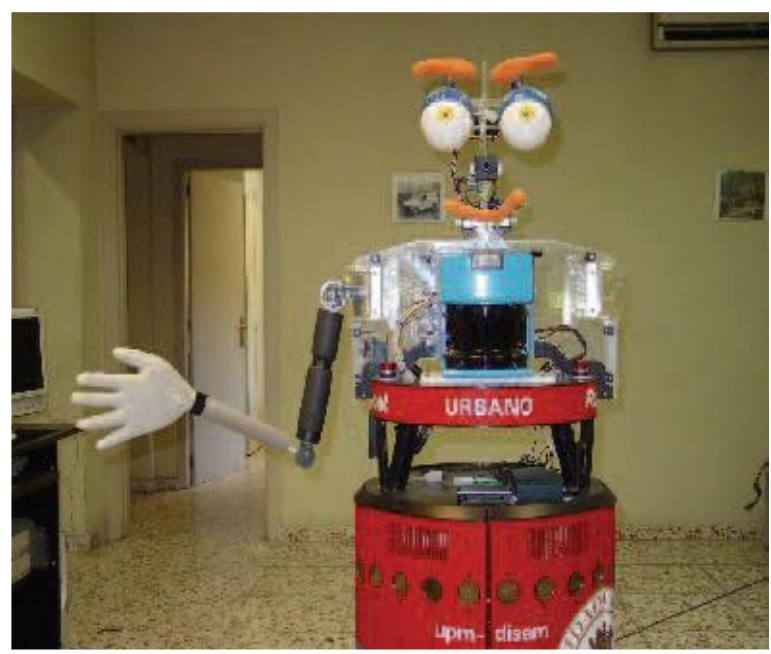

Figure 1: Urbano
2) Blacky (Fig. 2) is fully autonomous robot having capability of interacting people, and it can able to navigate safely in an environment [21].

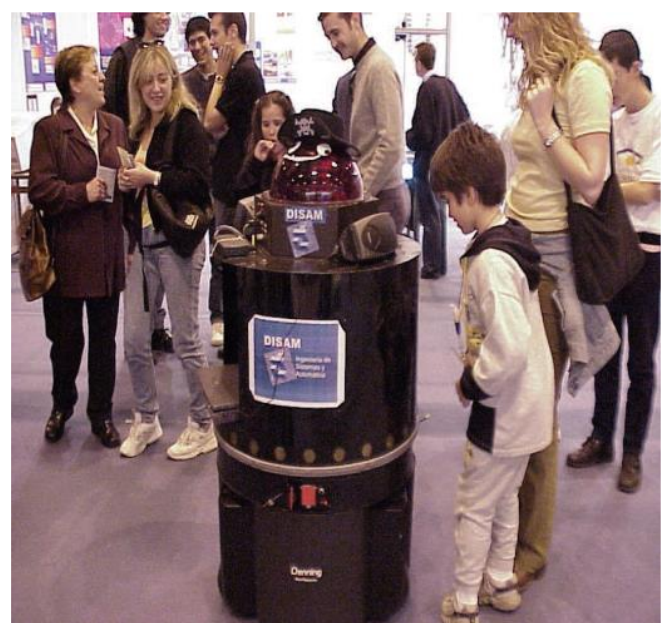

Figure 2: Blacky robot in a fair

3) PolyUiBot (Fig.3) is a robot that have special functioning of remotely access a user (client) can control over the internet or we can say that PolyUiBot creates a teleoperation platform. A camera is mounted on the top of a robot the robot server connect it over a wireless channel [6].
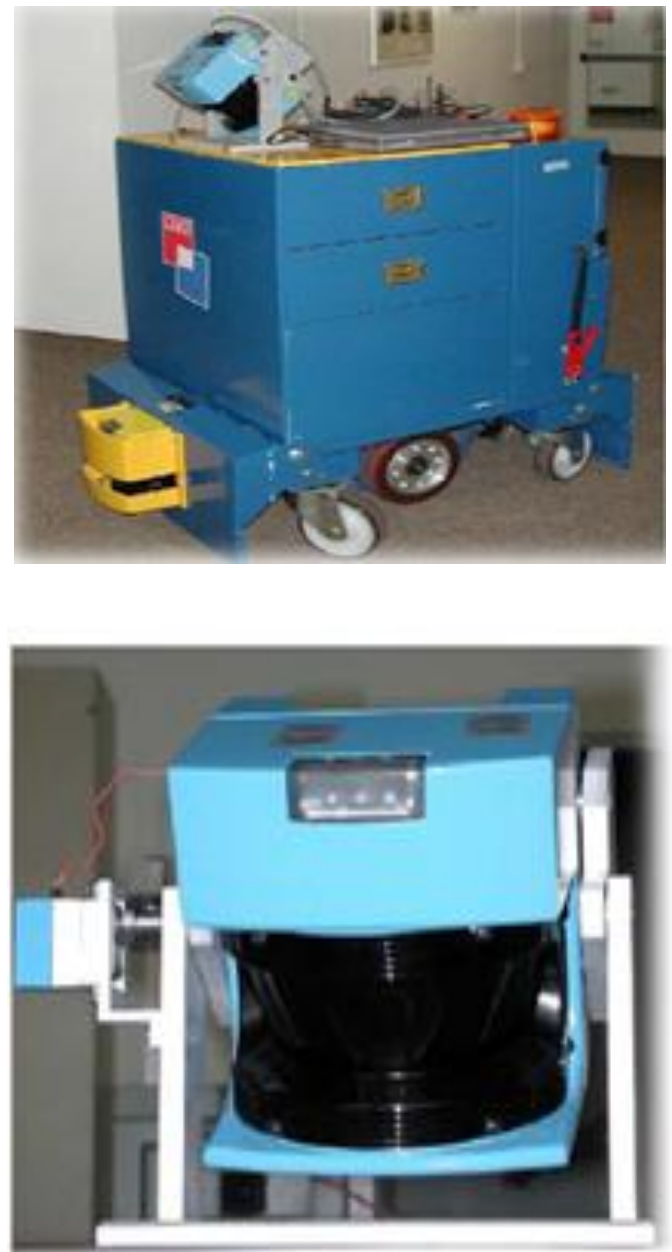

Figure 3: Ariadne robot platform [12] 
4) Wheel chair robot is smart robot capable of learn from human and through neural network it may be proceed in indoor or outdoor environment [9].

5) The Ariadane robot is very special purpose robot which can communicate to the surrounding environment [12].

6) Cobot is custom built robot having Wifi based localization algorithm used mainly in indoor environment [13].

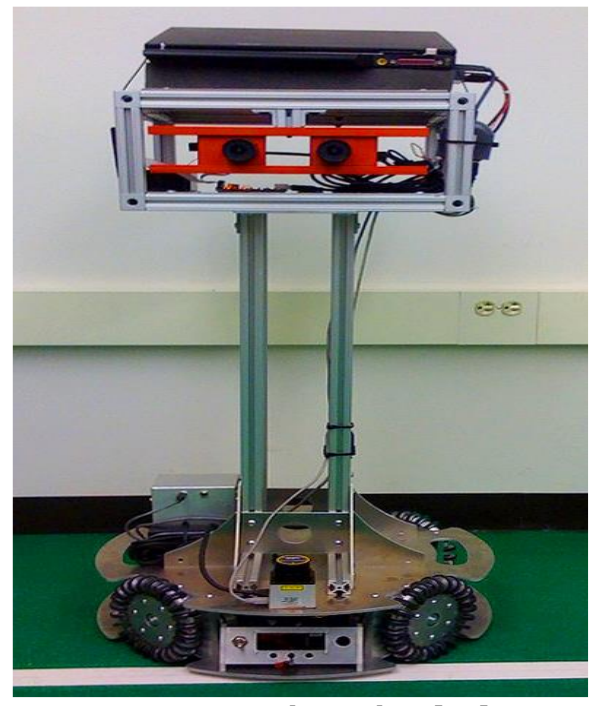

Figure 4: Cobot robot [13]

\section{Fully Indigenous Guide Robot 'Pratham'}

A fully indigenous guide and multimedia robot, is designed to welcome guests and visitors and guide them for campus-tour with appropriate multimedia information. 'Pratham' is programmed so that it can pick up the visitors from the main reception and guide them to few pre-defined areas of University campus (such as, R\&D center, library, placement block, MDC) and there after culminate back at main reception. Mobile guide equipped with 5- Axis arm, adjustable height of HDMI display, encoder motors, sonar sensor, Zigbee \& digital compass sensor.

It is capable to speak the pre-programmed information. It can interact with visitors and play multimedia on screen.

The robot can be operated in two modes:

\section{$>$ Autonomous Mode}

In Autonomous mode the robot can move by encoder wheels, Digital compass, Bumpers and sonar sensor. The different parameters of the robot are set to default values or to the values that are set by the user through serial communication.

The microcontroller is interfaced with the sensors. It receives data from these sensors and analyze them to take proper decisions about movement of robot.

After taking the accurate decisions it gives appropriate instructions to the motor for movement.

\section{User Mode}

The default mode of PRATHAM is 'USER MODE'.

The robot in this mode is guided by the user unlike in the autonomous mode where only microcontroller controls the complete functioning of robot.

The method of operating robot in this mode is done with the help of two PCs, one is off board PC connected wirelessly and one which is connected with the robot act as on board PC. Google API, Google translate services for mimicry.

The time lapse camera control to live capture the surrounding image and surrounding audio is capture through microphone.

Fig. 5 shows the overall RF links of the robot in the campus.

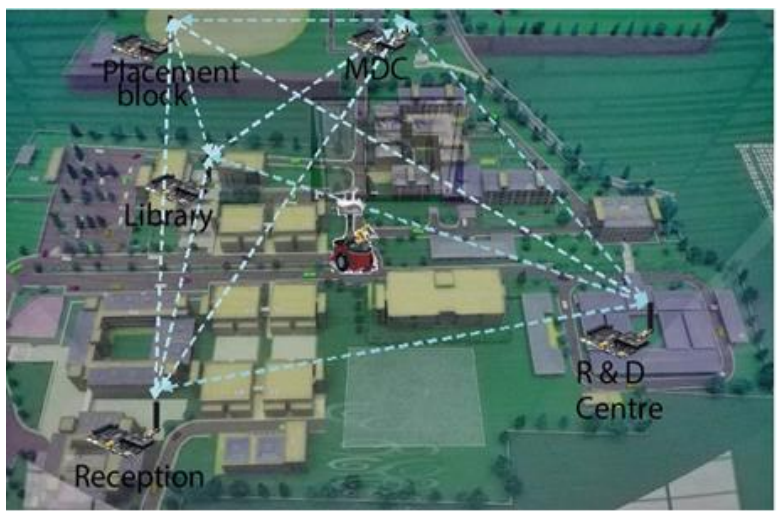

Figure 5: RF Link of Robot in UPES, Dehradun

Data collection form the following nodes and individual testing

1- Placement Block

2- Library

3- Reception

4- R \& D Centre

5- MDC

\subsection{System Architecture}

Robot is built to entertain and provide a glimpse of the University campus and its facilities. Zigbee nodes are placed at few pre-defined locations and when robot reach in its range, it start playing the information regarding that location.

Key features of the robot:

1. On board computer RaspberryPi credit-cardsized single-board computer, used for multimedia support.

2. RFID, to initialize robot.

3. Robotic Arm, used to welcome guest by positioning 'NAMASKAR'

4. Google API- text to speech, internet services applicable.

5. Path- Learning with the help of encoded motors and compass.

6. Flexible system can be programmed according to the user. 
7. Zigbee are used to identify the location for any defined tasks multimedia or guide is to be done.

8. Explain about the blocks through video/audio and displaying some it on HDMI display.

9. Respond to visitors questions through predefined stored answers.

10. Connect people all around the world with a "virtual presence", using a Web interface to watch the robot operation and send it to specific target locations.
Fig. 6 shows the complete system architecture of the robot. The complete system comprises of sensor nodes (deployed at different locations in the campus), control unit, user remote control, master unit (onboard computer) and two slave units (servo controller and robo controller).

Fig. 7 shows the block diagram of slave unit1comprises of LPC1728 (controller), sonar, bumper, compass, motor driver, motors and RF modem.

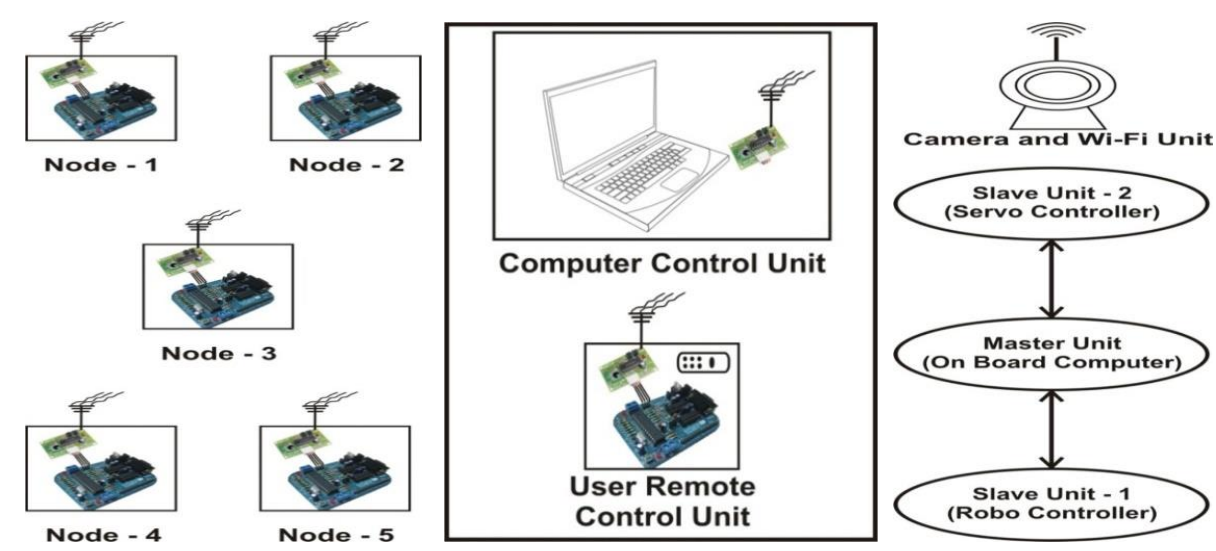

Figure 6: System Architecture

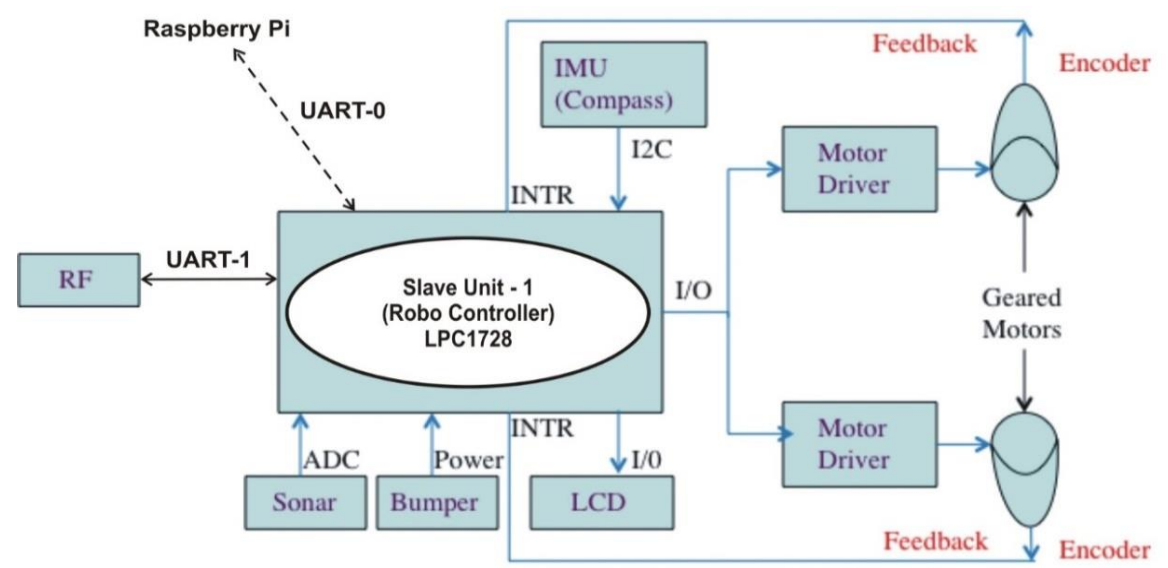

Figure 7: Block diagram of Slave Unit1

Fig. 8 shows block diagram of slave unit-2 comprises of Atmega328, servo, RFID tag and switches.

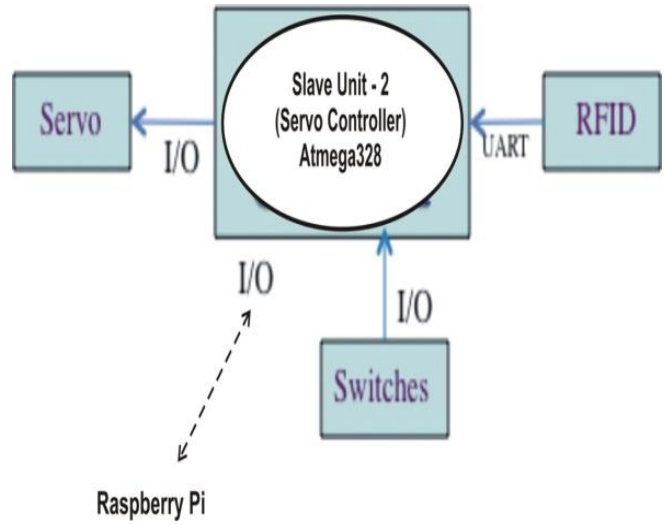

Figure 8: Block diagram of Slave Unit2
Fig.9 shows the block diagram of master unit comprises of raspberry pi, speaker and LED display for video.

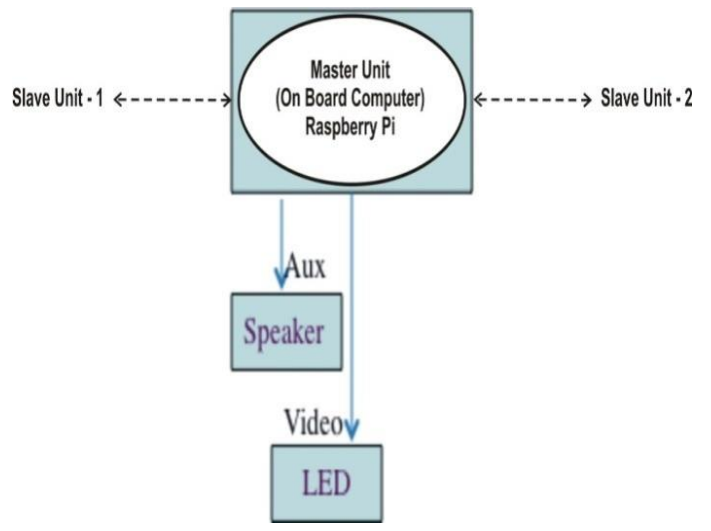

Figure 9: Block diagram of Master Unit 
CAD model of the robot

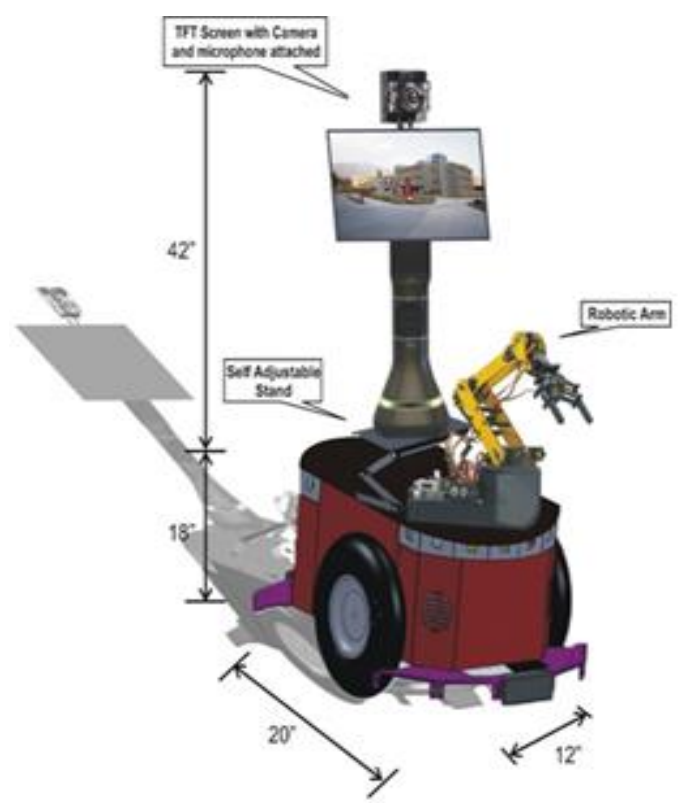

Figure 10: CAD model of proposed structure

Table 1. Technical specifications

\begin{tabular}{|c|c|c|c|c|c|}
\hline \multicolumn{2}{|c|}{ Mechanical Specifications } & \multicolumn{2}{|c|}{ Software Specifications } & \multicolumn{2}{|c|}{ Electronics Specifications } \\
\hline \multicolumn{2}{|c|}{ Specifications $\quad$ Benefits } & \multicolumn{2}{|c|}{ Specifications $\quad$ Benefits } & Specifications & \multirow{2}{*}{$\begin{array}{c}\text { Benefits } \\
\text { No moving } \\
\text { disks } 1 \text { x Serial } \\
\text { ports }\end{array}$} \\
\hline $\begin{array}{c}\text { Two wheel } \\
\text { Differential } \\
\text { drive }\end{array}$ & $\begin{array}{l}\text { For smooth } \\
\text { drive }\end{array}$ & $\begin{array}{l}\text { Raspberry-Pi } \\
\text { running Linux }\end{array}$ & $\begin{array}{l}\text { Wide range in } \\
\text { multimedia } \\
\text { support }\end{array}$ & $\begin{array}{l}\text { Rugged solid } \\
\text { state } \\
\text { components }\end{array}$ & \\
\hline $\begin{array}{l}1024 \text { tick } \\
\text { encoded } \\
\text { motors, } \\
19.5 \mathrm{~cm} \\
\text { wheels }\end{array}$ & $\begin{array}{c}\text { For } \\
\text { autonomous } \\
\text { mode }\end{array}$ & $\underset{\text { Programming in }}{\text { "C" }}$ & $\begin{array}{l}\text { For configuring } \\
\text { general sensors } \\
\text { and motors }\end{array}$ & Accelerometer & Avoid tilting \\
\hline $\begin{array}{c}\text { Sturdy all- } \\
\text { metal chassis }\end{array}$ & For rigidness & $\begin{array}{l}\text { Programming of } \\
\text { Arduino board. }\end{array}$ & For robotic arm. & $\begin{array}{l}\text { Rugged solid } \\
\text { state } \\
\text { components }\end{array}$ & $\begin{array}{l}\text { no moving } \\
\text { disks }\end{array}$ \\
\hline $\begin{array}{l}\text { Speed upto } \\
0.5 \\
\text { metre/sec. } \\
\text { and Payload } \\
\text { upto } 20 \text { kgs. }\end{array}$ & $\begin{array}{l}\text { make it } \\
\text { capable for } \\
\text { work in } \\
\text { tough } \\
\text { condition }\end{array}$ & $\begin{array}{l}\text { Embedded ARM- } \\
\text { cortex based } \\
100 \mathrm{MHz} \\
\text { microcontroller } \\
\text { board }\end{array}$ & fast processing & $\begin{array}{l}1 \text { x Serial ports } \\
\text { (USB Hub) }\end{array}$ & $\begin{array}{l}\text { (Can easily be } \\
\text { extended up to } \\
\text { 2) }\end{array}$ \\
\hline $\begin{array}{l}\text { Powered by } \\
\text { three hot- } \\
\text { swappable } \\
\text { SMF } \\
\text { batteries. }\end{array}$ & $\begin{array}{l}\text { For its long } \\
\text { life }\end{array}$ & $\begin{array}{c}\text { Scalable } \\
\text { firmware } \\
\text { architecture }\end{array}$ & $\begin{array}{c}\text { For re- } \\
\text { programming }\end{array}$ & $\begin{array}{l}\text { USB Wi-Fi } \\
\text { routers }\end{array}$ & For interaction \\
\hline $\begin{array}{l}\text { Height } \\
\text { Adjustable } \\
\text { LCD stand }\end{array}$ & $\begin{array}{c}\text { for make it } \\
\text { user friendly }\end{array}$ & Open source & $\begin{array}{c}\text { user friendly } \\
\text { operating system }\end{array}$ & $\begin{array}{c}\text { USB Camera } \\
\text { USB } \\
\text { microphone. } \\
\text { Stereo Speakers }\end{array}$ & Audio-Video \\
\hline $\begin{array}{c}\text { Fault tolerant } \\
\text { design- }\end{array}$ & $\begin{array}{l}\text { To make it } \\
\text { smart and } \\
\text { intelligent }\end{array}$ & & & $\begin{array}{l}\text { Front and rear } \\
\text { segmented } \\
\text { bumpers }(1 \times 5)-\end{array}$ & $\begin{array}{l}\text { Avoid accidents } \\
\text { and obstacles } \\
\text { in the path }\end{array}$ \\
\hline
\end{tabular}


Fig. 11: (a), (b), (c) shows different steps for mechanical structure of the robot.

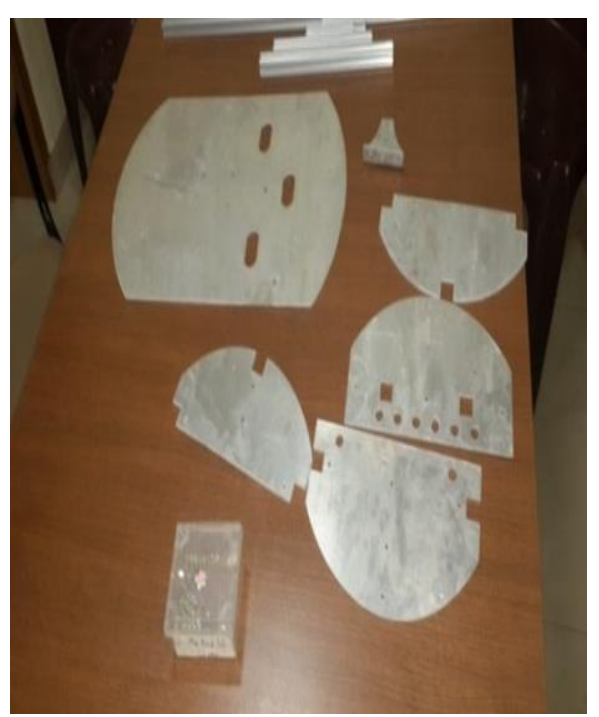

(a)

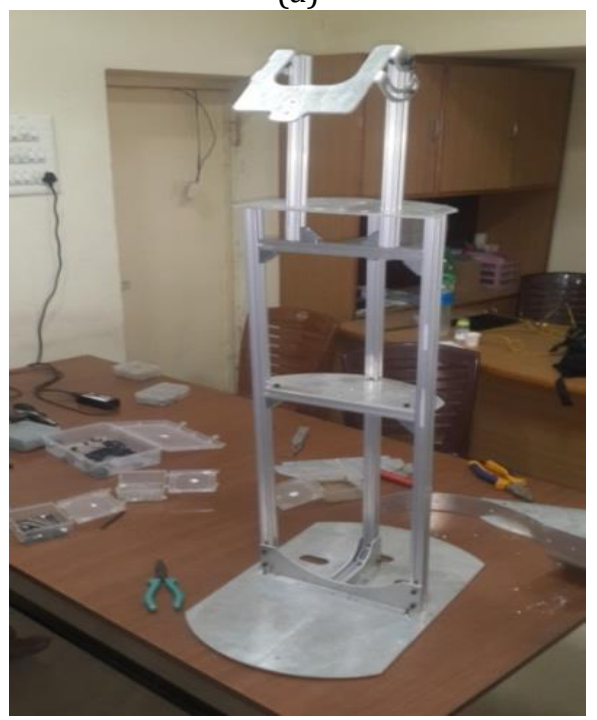

(b)

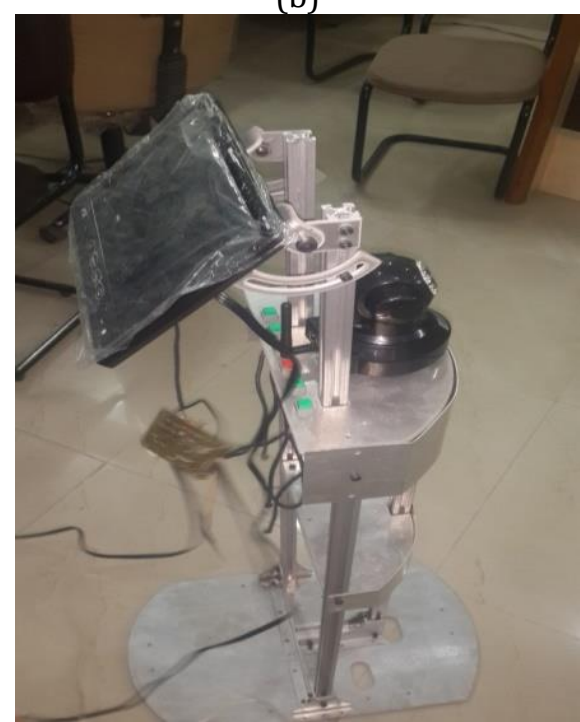

(c)

\section{Software Development and System evaluation}

Fig. 12 shows the flow chart of the obstacle avoidance algorithm, developed for the robot.

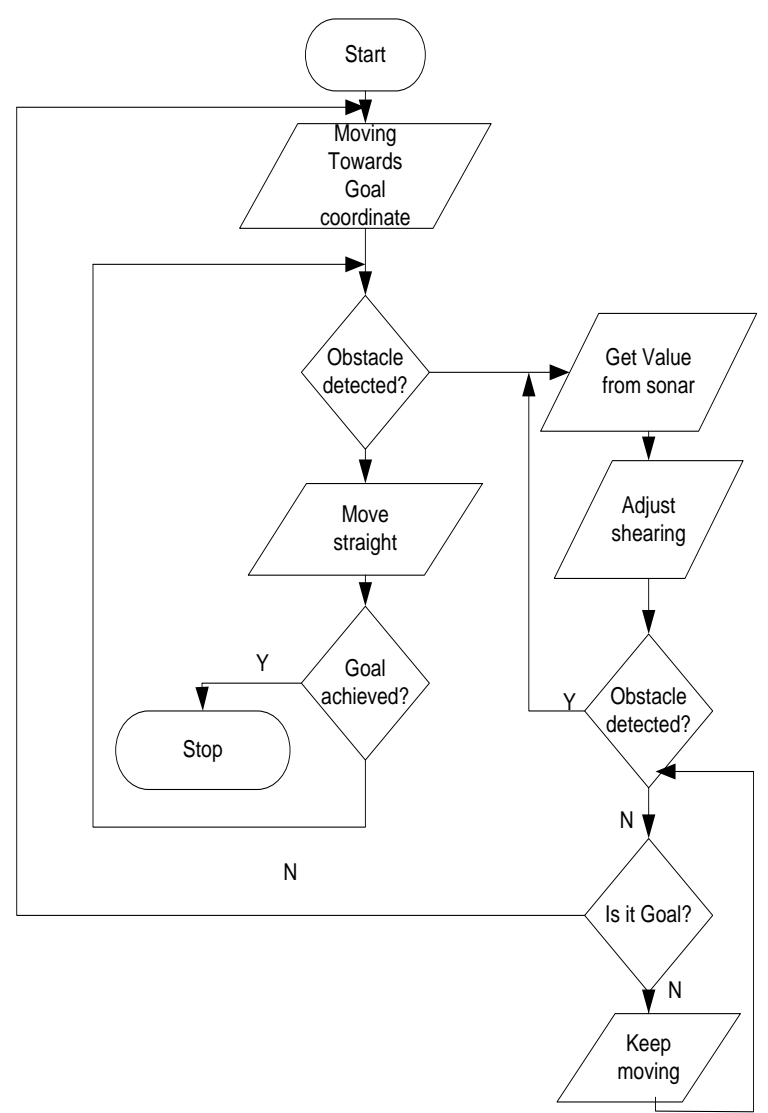

Figure 12: Algorithm for obstacle avoidance

\subsection{Obstacle avoidance using bubble rebound}

Assume the sonar cells are distributed uniformly at the angular pace:

$$
\theta_{0}=\frac{\pi}{N}
$$

Then the index of sonar, $j$ contains the information of angle:

$$
\begin{aligned}
& \theta_{j}=j \theta_{0} \\
& \theta_{j} \in\left[-\frac{N}{2}, \frac{N}{2}\right]
\end{aligned}
$$

Where $\mathrm{N}=$ number of sonar cells From these notations the resultant rebound angle is:

$$
\theta_{R}=\frac{\sum_{j=-N / 2}^{N / 2} \theta_{j} X_{j}}{\sum_{j=-N / 2}^{N / 2} X_{j}}
$$

Figure 11: Mechanical structure designing of robot 


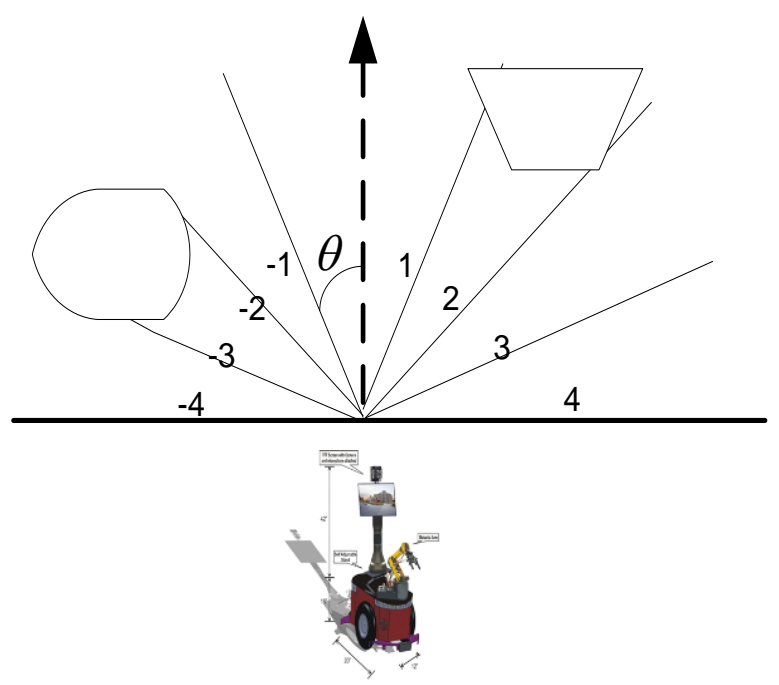

Figure 13: Computing rebound angle

Fig. 14 shows the route map of robot with respect to RF nodes.

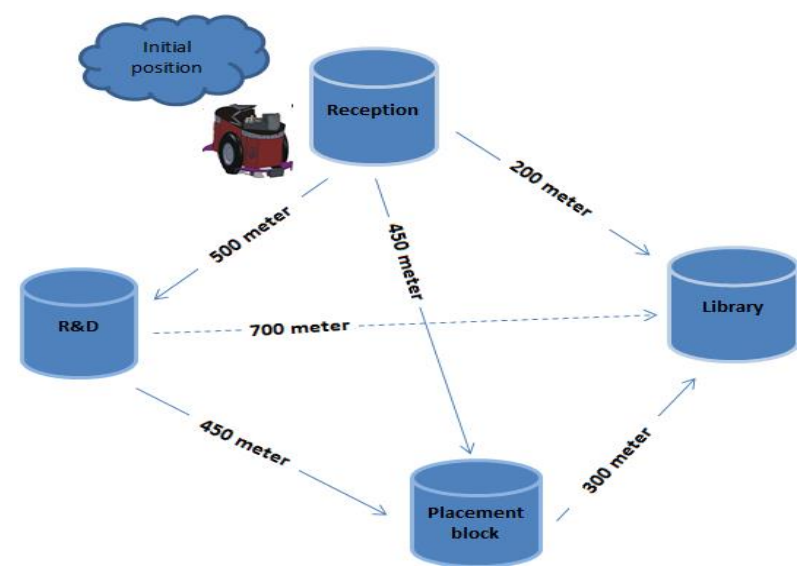

Figure 14: Route map of robot with respect to $R F$ nodes

\section{Results and Conclusion}

Robot is trained to follow a pre defined path with training Table2 \& 3 describes the calculation of distance and time with respect to route.

Table 2. Training data set I (Calculation of distance and time with respect to route)

\begin{tabular}{|c|c|c|c|c|c|}
\hline S.no & & $\frac{\text { oving state }}{\text { nitialGoal }}$ & $\frac{\text { Total Distance }}{\text { (in meter) }}$ & $\begin{array}{l}\text { Time } \\
\text { taken } \\
\text { (in } \\
\text { minute }\end{array}$ & $\begin{array}{c}\text { Total number of rotation } \\
\text { (Encoder value per rotation } \\
1 \text { 1024) } \\
\text { [wheel diameter }=19.5 \mathrm{~cm} \text { ] }\end{array}$ \\
\hline $\begin{array}{c}\text { CASE } \\
1\end{array}$ & Reception & Library & 200 & 6.666 & $\begin{array}{c}(200 * 100) / 19.5=1025.641 \\
(1026 \text { approx. })\end{array}$ \\
\hline $\begin{array}{l}\text { CASE } \\
2 .\end{array}$ & Reception & Placement block & 450 & 15 & $\begin{array}{c}(450 * 100) / 19.5=2307.69 \\
(2308 \text { approx.) }\end{array}$ \\
\hline $\begin{array}{l}\text { CASE } \\
3 .\end{array}$ & Reception & R\&D & 500 & 16.666 & $\begin{array}{c}(500 * 100) / 19.5=2564.102 \\
\text { (2564 approx.) }\end{array}$ \\
\hline $\begin{array}{l}\text { CASE } \\
4 .\end{array}$ & Library & Placement block & 300 & 10 & $\begin{array}{c}(300 * 100) / 19.5=1538.461 \\
\text { (1539 approx.) }\end{array}$ \\
\hline $\begin{array}{l}\text { CASE } \\
5 .\end{array}$ & Library & R\&D & 700 & 23.333 & $\begin{array}{c}(700 * 100) / 19.5=3589.743 \\
\text { (3590 approx.) }\end{array}$ \\
\hline $\begin{array}{l}\text { CASE } \\
6 .\end{array}$ & $\begin{array}{l}\text { Placement } \\
\text { block }\end{array}$ & R\&D & 450 & 15 & $\begin{array}{c}(450 * 100) / 19.5=2307.69 \\
(2308 \text { approx.) }\end{array}$ \\
\hline $\begin{array}{l}\text { CASE } \\
7 .\end{array}$ & Reception & $\begin{array}{l}\text { Library, Placement } \\
\text { block }\end{array}$ & $200+300=500$ & 16.666 & $\begin{array}{c}(500 * 100) / 19.5=2564.102 \\
(2564 \text { approx.) }\end{array}$ \\
\hline $\begin{array}{l}\text { CASE } \\
8 .\end{array}$ & Reception & Placement block, R\&D & $450+450=900$ & 30 & $\begin{array}{c}(900 * 100) / 19.5=4615.384 \\
(4615 \text { approx. })\end{array}$ \\
\hline $\begin{array}{l}\text { CASE } \\
9 .\end{array}$ & Reception & Library, R\&D & $200+700=900$ & 30 & $\begin{array}{c}(900 * 100) / 19.5=4615.384 \\
\text { (4615 approx.) }\end{array}$ \\
\hline $\begin{array}{l}\text { CASE } \\
10 .\end{array}$ & Library & Placement block, R\&D & $300+450=750$ & 25 & $\begin{array}{c}(750 * 100) / 19.5=3846.153 \\
\text { (3846 approx.) }\end{array}$ \\
\hline $\begin{array}{l}\text { CASE } \\
11 .\end{array}$ & Reception & $\begin{array}{l}\text { Library, Placement } \\
\text { block, Reception }\end{array}$ & $200+300+450=950$ & 31.666 & $\begin{array}{c}(950 * 100) / 19.5=4871.794 \\
(4872 \text { approx.) }\end{array}$ \\
\hline $\begin{array}{l}\text { CASE } \\
12 .\end{array}$ & Reception & $\begin{array}{l}\text { Placement block, R\&D, } \\
\text { Reception }\end{array}$ & $450+450+500=1400$ & 46.666 & $\begin{array}{c}(1400 * 100) / 19.5=7179.48 \\
\text { (7180 approx.) }\end{array}$ \\
\hline $\begin{array}{l}\text { CASE } \\
13 .\end{array}$ & Reception & $\begin{array}{l}\text { R\&D, Library, } \\
\text { Reception }\end{array}$ & $200+500+700=1400$ & 46.666 & $\begin{array}{c}(1400 * 100) / 19.5=7179.48 \\
\text { (7180 approx.) }\end{array}$ \\
\hline $\begin{array}{c}\text { CASE } \\
14 .\end{array}$ & Reception & $\begin{array}{l}\text { Library, R\&D, } \\
\text { Placement block, } \\
\text { Reception }\end{array}$ & $\begin{array}{c}200+300+450+500= \\
1450\end{array}$ & 48.333 & $\begin{array}{c}(1450 * 100) / 19.5=7435.89 \\
(7436 \text { approx.) }\end{array}$ \\
\hline
\end{tabular}


Table 3. Training data set II (Heading in degree)

\begin{tabular}{|c|c|c|c|c|c|c|c|c|c|c|}
\hline \multirow{2}{*}{ S.no } & \multicolumn{2}{|c|}{ Moving state } & \multicolumn{8}{|c|}{ Heading in degree (using magneto meter and compass) } \\
\hline & Initial & Goal & $\mathbf{N}$ & $\mathbf{S}$ & $\mathbf{E}$ & $\mathbf{W}$ & NE & NW & SE & SW \\
\hline CASE 1 & Reception & Library & 75 & & & & & & & \\
\hline CASE 2. & Reception & Placement block & 85 & & & & & & & \\
\hline CASE 3. & Reception & R\&D & & & & & 50 & & & \\
\hline CASE 4. & Library & Placement block & & & & & & 110 & & \\
\hline CASE 5. & Library & R\&D & & 30 & & & & & & \\
\hline CASE 6. & Library & Reception & & & & & & & & 105 \\
\hline CASE 7. & $\begin{array}{l}\text { Placement } \\
\text { block }\end{array}$ & $R \& D$ & & & & & & & 60 & \\
\hline CASE 8. & $\begin{array}{l}\text { Placement } \\
\text { block }\end{array}$ & Library & & 80 & & & & & & \\
\hline CASE 9. & $\begin{array}{l}\text { Placement } \\
\text { block }\end{array}$ & Reception & & & & & & & & 95 \\
\hline CASE 10. & $R \& D$ & Placement block & & & & & & 120 & & \\
\hline CASE 11. & R\&D & Reception & & & & & & & & 130 \\
\hline CASE 12. & $R \& D$ & Library & & & & & & 150 & & \\
\hline
\end{tabular}

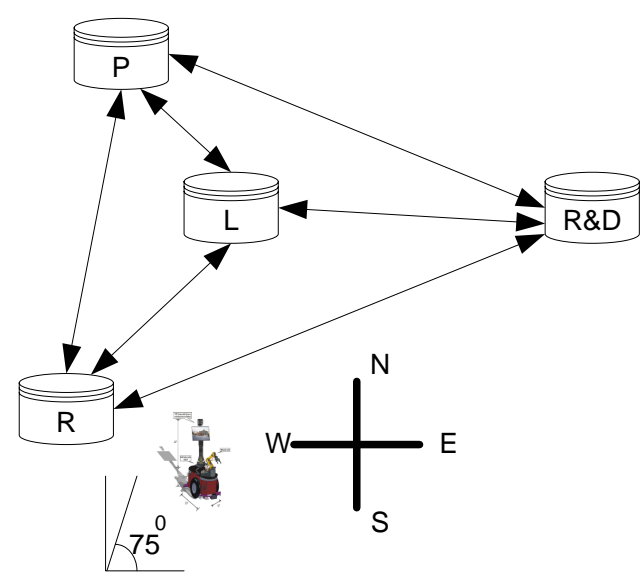

a)

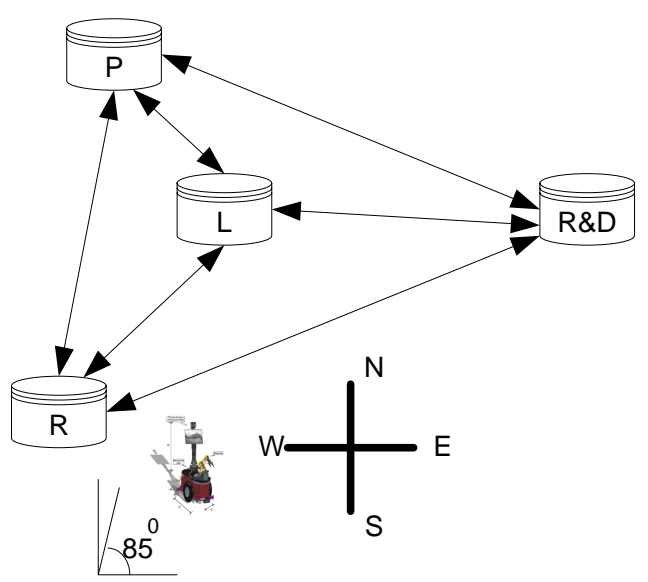

b)

Figure 15: (a), (b) representation of headings in degree (at origin reception)

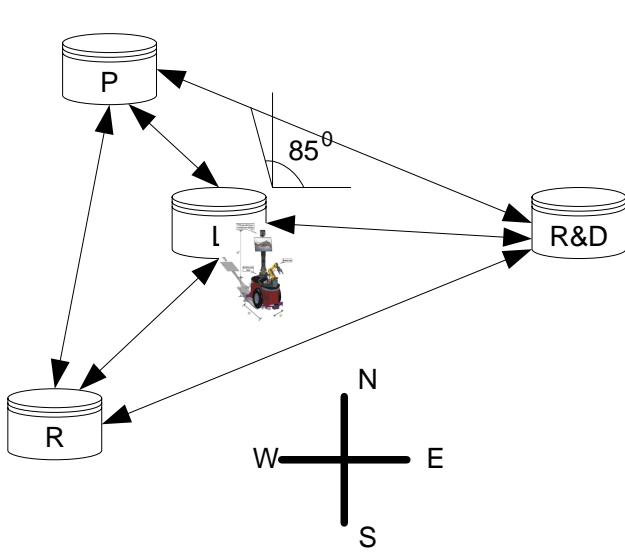

c)

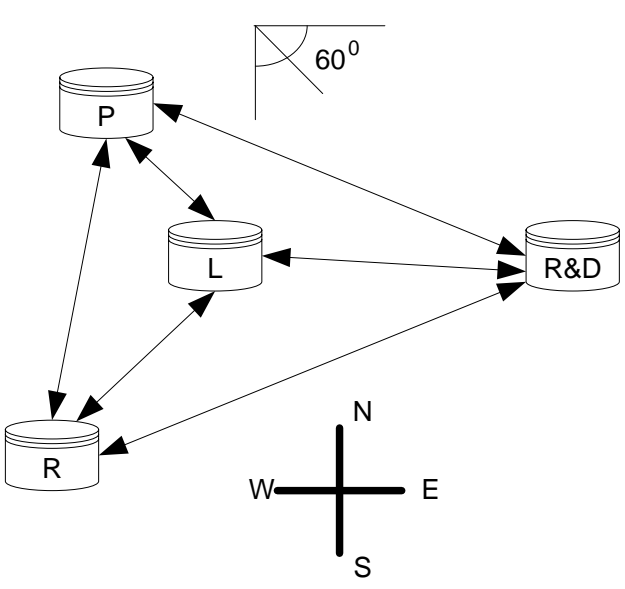

d)

Figure 15: (c), (d) representation of headings in degree (at origin Library) 
Table: 4, 5, 6 shows the trail of the robot on pre defined path and error correction.

\begin{tabular}{|c|c|c|}
\hline $\begin{array}{c}\text { Heading } \\
\text { (in degree) }\end{array}$ & $\begin{array}{c}\text { Distance (in } \\
\text { inches) }\end{array}$ & Nodes \\
\hline 320 & 100 & $\begin{array}{c}\text { Node } 1 \\
\text { (Reception) }\end{array}$ \\
\hline 230 & 20 & \\
\hline 160 & 48 & $\begin{array}{c}\text { Node } 2 \\
\text { (Library) }\end{array}$ \\
\hline 80 & 98 & \\
\hline 300 & 45 & Node 3 (R\&D) \\
\hline 200 & 50 & \\
\hline 38 & 38 & $\begin{array}{c}\text { Node } 4 \\
\text { (Placement } \\
\text { Block) }\end{array}$ \\
\hline
\end{tabular}

Remarks: Distortion of 29 degree in node2 Result: Attempt 1 distorted

Table 5. Trial 2

\begin{tabular}{|c|c|c|}
\hline $\begin{array}{c}\text { Heading } \\
\text { (in degree) }\end{array}$ & $\begin{array}{c}\text { Distance } \\
\text { (in inches) }\end{array}$ & Nodes \\
\hline 300 & 100 & Node 1 (reception) \\
\hline 200 & 20 & \\
\hline 180 & 48 & Node 2 (Library) \\
\hline 63 & 98 & Node 3 (R\&D) \\
\hline 321 & 45 & Node 4 (Placement \\
\hline 210 & 50 & Block) \\
\hline 39 & 38 & $\begin{array}{c}\text { Back node 1 } \\
\text { (Reception) }\end{array}$ \\
\hline 230 & 90 \\
\hline 23 & 48 & \multicolumn{2}{|c}{} \\
\hline
\end{tabular}

Remarks: Distortion of 29 degree in node2 was resolved.

Result: problem in fetching data from node 3

Table 6. Trial 3

\begin{tabular}{|c|c|c|}
\hline $\begin{array}{c}\text { Heading } \\
\text { (in degree) }\end{array}$ & $\begin{array}{c}\text { Distance } \\
\text { (in inches) }\end{array}$ & Nodes \\
\hline 300 & 100 & $\begin{array}{c}\text { Node 1 } \\
\text { (Reception) }\end{array}$ \\
\hline 200 & 20 & $\begin{array}{c}\text { Node 2 } \\
\text { (Library) }\end{array}$ \\
\hline 180 & 48 & Node 3 (R\&D) \\
\hline 63 & 98 & $\begin{array}{c}\text { Node 4 } \\
\text { (Placement } \\
\text { Block) }\end{array}$ \\
\hline 321 & 45 & \\
\hline 210 & 38 & $\begin{array}{c}\text { Back to Node 1 } \\
\text { (Reception) }\end{array}$ \\
\hline 230 & 90 & 48 \\
\hline
\end{tabular}

Remarks: Supply to node 3 is provided through $5 \mathrm{~V}$ adapter

Result: no error detected

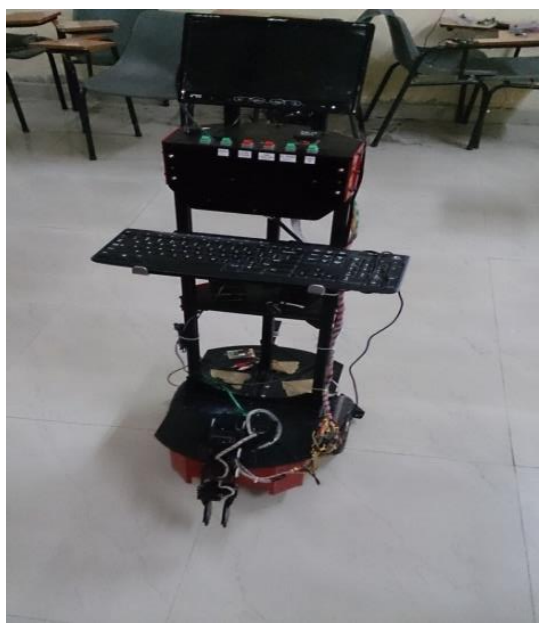

(a)

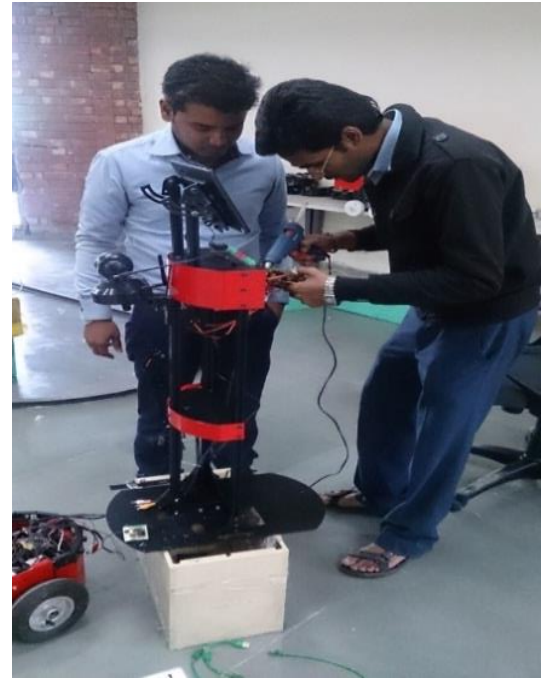

(b)

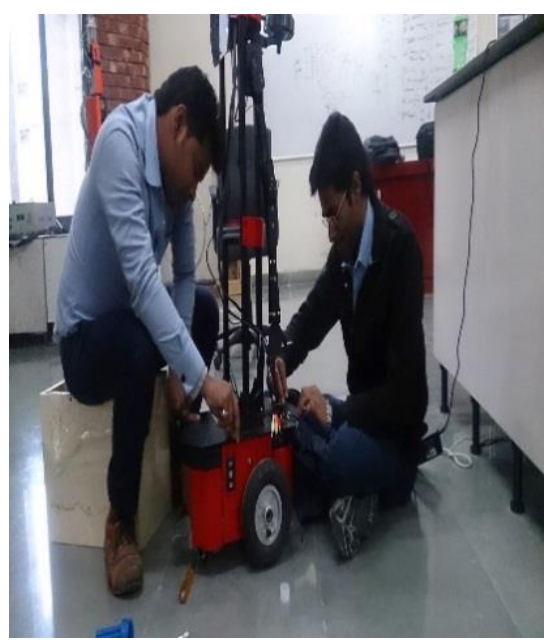

(c)

Figure 15: (a) View of system

(b) Fixing and communicating with AVR controls (c) Calibrating the Sensors 
Design of robot and verification of results has been performed and final result show no error in the path learning.

\section{Reference}

[1] Pai, Neng-Sheng, et al. "Implementation of a tour guide robot system using RFID technology and viterbi algorithm-based HMM for speech recognition." Mathematical Problems in Engineering 2014 (2014).

[2] Bennewitz, Maren, et al. "Learning motion patterns of people for compliant robot motion." The International Journal of Robotics Research 24.1 (2005): 31-48.

[3] Rodriguez-Losada, Diego, et al. "Urbano, an interactive mobile tour-guide robot." Advances in Service Robotics. InTech, 2008.

[4] Thrun, Sebastian, et al. "Probabilistic algorithms and the interactive museum tour-guide robot minerva." The International Journal of Robotics Research19.11 (2000): 972-999.

[5] López, Joaquin, Diego Pérez, and Eduardo Zalama. "A framework for building mobile single and multi-robot applications." Robotics and Autonomous Systems 59.3 (2011): 151-162.

[6] Wang, Meng, and James NK Liu. "Interactive control for Internet-based mobile robot teleoperation." Robotics and Autonomous Systems 52.2 (2005): 160-179.

[7] Sulaiman, Hamzah Asyrani, et al. "ToGouR: Tour guide robot visualization using shape recognition pattern for automatic navigation." International Journal of Engineering and Technology (IJET) (2013): 3275-3281.

[8] Javier Rainer, J., et al. "Apg: An intelligent automatic generator of presentations for tourguide robots." International Journal of Computational Intelligence Systems 4.4 (2011): 446-455.

[9] Chen, Zhichao, and Stanley T. Birchfield. "Qualitative vision-based path following." IEEE Transactions on Robotics 25.3 (2009): 749-754.

[10] Hua, Bin, et al. "Human-like Artificial Intelligent Wheelchair Robot Navigated by Multi-Sensor Models in Indoor Environments and Error Analysis." Procedia Computer Science 105 (2017): 14-19.

[11] Ssin, Seungyoub, et al. "Behavior Execution Method for a Robot Using an Online Development Approach." Frontier and Innovation in Future Computing and Communications. Springer, Dordrecht, 2014. 661-667.
[12] Surmann, Hartmut, Andreas Nüchter, and Joachim Hertzberg. "An autonomous mobile robot with a 3D laser range finder for 3D exploration and digitalization of indoor environments." Robotics and Autonomous Systems 45.3 (2003): 181-198.

[13] Biswas, Joydeep, and Manuela Veloso. "Wifi localization and navigation for autonomous indoor mobile robots." Robotics and Automation (ICRA), 2010 IEEE International Conference on. IEEE, 2010.

[14] Bonin-Font, Francisco, Alberto Ortiz, and Gabriel Oliver. "Visual navigation for mobile robots: A survey." Journal of intelligent and robotic systems 53.3 (2008): 263.

[15] Liu, Hui, et al. "Survey of wireless indoor positioning techniques and systems." IEEE Transactions on Systems, Man, and Cybernetics, Part C (Applications and Reviews) 37.6 (2007): 1067-1080.

[16] Chen, Haoyao, et al. "Localization for multirobot formations in indoor environment." IEEE/ASME Transactions on Mechatronics 15.4 (2010): 561-574.

[17] Choi, Byoung-Suk, et al. "A hierarchical algorithm for indoor mobile robot localization using RFID sensor fusion." IEEE Transactions on Industrial Electronics 58.6 (2011): 22262235.

[18] Nguyen, Viet, et al. "A comparison of line extraction algorithms using 2D range data for indoor mobile robotics." Autonomous Robots 23.2 (2007): 97-111.

[19] Ranganathan, Parthasarathy, et al. "Topological navigation and qualitative localization for indoor environment using multi-sensory perception." Robotics and Autonomous systems 41.2 (2002): 137-144.

[20] Lee, Dongheui, and Woojin Chung. "Discretestatus-based localization for indoor service robots." IEEE Transactions on Industrial Electronics 53.5 (2006): 1737-1746.

[21] Rodriguez-Losada, Diego, et al. "Blacky, an interactive mobile robot at a trade fair." Robotics and Automation, 2002. Proceedings. ICRA'02. IEEE International Conference on. Vol. 4. IEEE, 2002.

[22] Feng, Yanpeng, and Bo Wu. "Robot path planning algorithm based on partially observable Markov." Journal of Intelligent \& Fuzzy Systems Preprint: 1-6

[23] Jiang, Ping, Quansheng Dou, and Xiaoying Hu. "A supervised method for retinal image vessel segmentation by embedded learning and classification." Journal of Intelligent \& Fuzzy Systems Preprint (2015): 1-11. 